\title{
Effect of Exercise on Markers of Vascular Health in Renal Transplant Recipients
}

\author{
J. PIŤHA ${ }^{1}$, I. KRÁLOVÁ LESNÁ ${ }^{1}$, P. STÁVEK ${ }^{1}$, A. MAHROVÁ ${ }^{2}$, J. RACEK ${ }^{3}$, \\ A. SEKERKOVÁ ${ }^{4}$, V. TEPLAN ${ }^{5}$, M. ŚTOLLOVÁ ${ }^{5}$
}

${ }^{1}$ Center for Experimental Medicine, Institute for Clinical and Experimental Medicine, Prague, Czech Republic, ${ }^{2}$ Faculty of Physical Education and Sport, Charles University, Prague, Czech Republic, ${ }^{3}$ Institute of Clinical Biochemistry and Hematology, Medical Faculty Charles University, Pilsen, Czech Republic, ${ }^{4}$ Department of Clinical and Transplant Immunology, Institute of Clinical and Experimental Medicine, Prague, Czech Republic, ${ }^{5}$ Department of Nephrology, Transplant Center, Institute for Clinical and Experimental Medicine, Prague, Czech Republic

Received June 8, 2015

Accepted June 29, 2015

On-line October 8, 2015

\section{Summary}

The cornerstone of cardiovascular risk management is lifestyle intervention including exercise which could exert favorable impact also in renal transplant recipients. Nevertheless, reliable assessment of the effect of lifestyle interventions is complicated and the available data in this population are not consistent. The aim of the study was to evaluate the effect of physical activity on selected laboratory markers of vascular health including circulating stem cells, endothelial progenitor cells, microparticles, and plasma asymmetric dimethyl arginine in renal transplant recipients. Nineteen men and 7 women were recruited in 6-month program of standardized and supervised exercise. Control group consisted of 23 men and 13 women of similar age and body mass index not included into the program. One year after the transplantation, the main difference between intervention and control group was found in the change of endothelial progenitor cells $(p=0.006)$. Surprisingly, more favorable change was seen in the control group in which endothelial progenitor cells significantly increased compared to the intervention group. The explanation of this finding might be a chronic activation of reparative mechanisms of vascular system in the population exposed to multiple risk factors which is expressed as relatively increased number of endothelial progenitor cells. Therefore, their decrease induced by exercise might reflect stabilization of these processes.
\end{abstract}

\section{Key words}

Renal transplantation • Exercise • Endothelial progenitor cells • Circulating microparticles • Asymmetric dimethyl arginine

\section{Corresponding author}

J. Pit'ha, Laboratory for Atherosclerosis Research, Center for Experimental Medicine, Institute for Clinical and Experimental Medicine, Vídeňská 1958/9, 14021 Prague 4, Czech Republic. E-mail: japi@ikem.cz

Cardiovascular disease caused by atherosclerosis remains a major cause of morbidity and mortality in patients with end-stage renal disease including renal transplant recipients. The high risk of patients with endstage renal disease including those after kidney transplantation is undoubtedly caused by the increased prevalence of traditional cardiovascular risk factors including higher age, smoking, hypertension, diabetes mellitus, and dyslipidemias. Cardiovascular complications in kidney transplant recipients can also be associated with a reduced number of circulating stem cells and endothelial progenitor cells. Circulating stem cells and endothelial progenitor cells are derived from bone marrow, mature into endothelium and are crucial in endothelial recovery after ischemic and other injuries to 
vascular system (Ulbich et al. 2004, Steiner et al. 2006). Their concentrations are, therefore, used for reliable assessment of vascular status. Circulating microparticles are also a usable marker for vascular damage and are used to assessment of changes of cardiovascular risk in various populations - including the study of our laboratory (Ivak et al. 2014). Asymmetric dimethyl arginine belongs to frequently discussed biomarkers which could reflect vascular status and indicate increased cardiovascular risk (Boger et al. 2003). Among many therapeutic options, regular physical training has been shown to have a positive impact on asymmetric dimethyl arginine and endothelial progenitor cells in extremely high risk populations of patients with diabetes mellitus and peripheral artery disease (Mittermayer et al. 2005, Schlager et al. 2011). Nevertheless, the effects of regular exercise on all vascular parameters under study including circulating stem cells, endothelial progenitor cells, microparticles, and asymmetric dimethyl arginine in renal transplant recipients was to our best knowledge not yet studied.

The aim of this prospective study was to evaluate the effect of standardized exercise on parameters reflecting vascular function and health beyond traditional cardiovascular risk factors in renal transplant recipients. Patients, who underwent first cadaveric renal transplantation at the Transplant Center Institute for Clinical and Experimental Medicine since January 1, 2012 and who agreed to participate in a supervised aerobic exercise program for six months, were included in the intervention group. The control group consisted of renal transplant recipients who did not exercise regularly and did not participate in the training program. Patients with a history of cardiovascular events were excluded. All patients were regularly treated with angiotensin converting enzyme inhibitors, angiotensin receptor blockers, and statins (based on blood-pressure control and laboratory parameters) and had no history of smoking. The study was approved by the Human Ethics Review Committee of the Institute for Clinical and Experimental Medicine (Prague, Czech Republic), and complies with the Declaration of Helsinki, including current revisions and the Good Clinical Practice Guidelines. The procedures followed were in accordance with institutional guidelines. All subjects gave written, informed consent before enrollment into the study. Patients from both groups were examined by the Clearance Laboratory of the Division of Metabolism at the Department of Nephrology (Transplant Center, Institute for Clinical and
Experimental Medicine, Prague, Czech Republic) within the period of 9 days to 7 months after renal transplantation. In the intervention group, physical condition was evaluated with "Senior Fitness Test-SFT" and HRQOL with standardized questionnaire SF36-Bref and enrolled patients participated in a 6-month training program of stationary cycling. All training was guided and supervised by a physician. The patients were also allowed to carry out an additional training program at home. Blood samples were taken at the first study visit and at 5-12 months after transplantation in patients from both groups (median 6 months). Plasma creatinine was measured after transplantation and one year after transplantation using an enzymatic colorimetric method with Olympus $\mathrm{AU} 600$ analyzer and reagents from Olympus Diagnostics, GmbH (Hamburg, Germany). Blood samples were collected into evacuated tubes with ethylenediaminetetraacetic acid, and the blood was immediately centrifuged. All patients fasted for at least $10 \mathrm{~h}$ before sampling to avoid the influence of methionine from food on asymmetric dimethyl arginine concentration. The detection of endothelial progenitor cells and stem cells in peripheral blood was performed using determination of surface antigen expression. Prior to staining with a specific monoclonal antibody, $200 \mu$ of peripheral blood was incubated with $40 \mu 1$ of fetal serum. Next, monoclonal antibody was added, i.e. $40 \mu 1$ of antiCD 34 conjugated with phycoerythrin (Beckman Coulter), $20 \mu 1$ antiCD 45 conjugated with fluorescein isothiocyanate (Beckman Coulter) and $10 \mu \mathrm{l}$ anti-KDR conjugated with Alexa Fluor 647 (e-Bioscience). Analyses were performed using an autoanalyzer (CyAn, Beckman Coulter), with each analysis assessing the expression of the monitored surface antigens per one million cells of peripheral blood. Based on human studies, stem cells were defined as mononuclear $\mathrm{CD} 34^{+} / \mathrm{CD} 45^{\text {low }}+$ cells and endothelial progenitor cells as $\mathrm{CD} 34^{+} / \mathrm{CD}_{4} 5^{\mathrm{low}}+/ \mathrm{KDR}^{+}$mononuclear cells. The concentration of microparticles was determined by ELISA Zymutest MP activity test (Hyphen Biomed, France) according to methodology established previously (Slavik et al. 2010) and expressed as nanomoles per liter relative to phosphatidylserine (nM PS). For asymmetric dimethyl arginine quantification, an enzyme-linked immunoassay method (Kit ADMA, ELISA, DLD Diagnostika GmbH, Hamburg, German) and an AUTOEIA II microplate reader (Labsystems Oy, Espoo, Finland) were used. Data are expressed as continuous variables with standard deviations and as categorical 
variables. To analyze differences in the case of continuous variables two-sample t-test with equal variances and for categorical variables $\chi^{2}$ Fischer exact test were used. Paired t-test was used for detection of changes before and after exercise and corresponding changes in control group, in both groups one year after renal transplantation. For all statistical analyses STATA program was used.

Table 1. Baseline data in the intervention and in the control group of renal transplant recipients.

\begin{tabular}{|c|c|c|c|}
\hline & Exercise & Control & $\begin{array}{l}\text { Exercise vs. Control } \\
\text { p (t test or } \chi^{2} \text { test) }\end{array}$ \\
\hline Age (years) & $\begin{array}{l}57.46 \pm 10.3 \\
\quad(n=26)\end{array}$ & $\begin{array}{l}54.81 \pm 12.0 \\
\quad(\mathrm{n}=36)\end{array}$ & 0.491 \\
\hline Women n (\%) & $7(27)$ & $13(36)$ & 0.584 \\
\hline $\begin{array}{l}\text { Hemodialysis/peritoneal dialysis before } \\
\text { transplantation } n(\%)\end{array}$ & $22 / 4(85 / 15)$ & $28 / 8(78 / 22)$ & 0.746 \\
\hline Body mass index $\left(\mathrm{kg} \cdot \mathrm{m}^{-2}\right)$ & $\begin{array}{l}27.9 \pm 5.2 \\
\quad(n=25)\end{array}$ & $\begin{array}{c}27.0 \pm 4.9 \\
(\mathrm{n}=35)\end{array}$ & 0.496 \\
\hline Creatinine after transplantation $(\mu \mathrm{mol} / \mathrm{l})$ & $\begin{array}{l}181.3 \pm 80.3 \\
\quad(n=26)\end{array}$ & $\begin{array}{l}170.9 \pm 53.6 \\
\quad(n=36)\end{array}$ & 0.715 \\
\hline Circulating stem cells (cells/ml) & $\begin{array}{l}2530 \pm 1540 \\
(\mathrm{n}=23)\end{array}$ & $\begin{array}{l}2258 \pm 1824 \\
\quad(n=28)\end{array}$ & 0.954 \\
\hline $\begin{array}{l}\text { Circulating endothelial progenitor cells } \\
(\text { cells } / \mathrm{ml})\end{array}$ & $\begin{array}{c}167 \pm 160 \\
(\mathrm{n}=23)\end{array}$ & $\begin{array}{c}119 \pm 144 \\
(n=28)\end{array}$ & 0.265 \\
\hline Circulating microparticles ( $n M P S^{*}$ ) & $\begin{array}{c}2.97 \pm 2.35 \\
(n=23)\end{array}$ & $\begin{array}{l}2.86 \pm 1.36 \\
(n=28)\end{array}$ & 0.835 \\
\hline Asymmetric dimethyl arginine $(\mu \mathrm{mol} / \mathrm{l})$ & $\begin{array}{c}0.738 \pm 0.162 \\
\quad(n=26)\end{array}$ & $\begin{array}{l}0.708 \pm 0.142 \\
\quad(n=36)\end{array}$ & 0.436 \\
\hline
\end{tabular}

Data are mean \pm SD (if not indicated differently), * nM PS: nanomoles per liter relative to phosphatidylserine.

Nineteen men and 7 women were recruited into 6-month standardized and supervised exercise intervention program (mean age $57.5 \pm 10.0$ years, mean body mass index $27.9 \pm 5.2 \mathrm{~kg} \cdot \mathrm{m}^{-2}$ ). The control group consisted of 23 men and 13 women of similar age $\left(54.8 \pm 12.0\right.$ years) and body mass index $\left(27.0 \pm 4.9\right.$ kg.m $\left.{ }^{-2}\right)$ without significant differences in all other parameters under study compared to the intervention group (Table 1). The changes in intervention and control group and differences between them are shown in Table 2 . In the intervention group, plasma creatinine $(\mathrm{p}=0.005)$, circulating stem cells $(\mathrm{p}=0.044)$, and asymmetric dimethyl arginine $(p=0.0006)$ were significantly decreased one year after transplantation; whereas no significant changes in endothelial progenitor cells and circulating microparticles were detected. In the control group, similar decreases in plasma creatinine $(p=0.0002)$ and asymmetric dimethyl arginine $(p=0.0037)$ were observed, but in contrast to the intervention group, less robust decrease of circulating stem cells $(p=0.191)$ was detected and, most importantly, endothelial progenitor cells and circulating microparticles were significantly increased $(p=0.015, p=0.0099)$. The only significant difference in the changes of parameters under study between intervention and control group was found in endothelial progenitor cells ( $\mathrm{p}=0.0062$ ), with a significant increase found in the control group.

In our previous study (Pitha et al. 2010) we detected sex-related differences in cardiovascular risk factors and preclinical atherosclerosis. Therefore, we also performed sex-oriented analyses of available data. From this point of view, no significant differences in parameters under study between exercising and control men or women were found with the exception of endothelial progenitor cells in men. Endothelial progenitor cells significantly increased in men from the control group $(+141 \pm 202$ cells $/ \mathrm{ml} ; \mathrm{p}=0.014)$ in contrast to a non-significant decrease in men from the intervention 
group $(-57 \pm 170$ cells $/ \mathrm{ml}, \mathrm{p}=0.217)$. The difference of changes in endothelial progenitor cells between these two groups was significant ( $p=0.0064)$ as it was in the whole group. In women similar findings were found, but the difference of changes between the intervention and control group was not significant (probably due to a low number of women). These findings were, therefore, identical as in the whole population.

Table 2. Changes in vascular parameters in renal transplant recipients in the intervention group after 6 months of exercise and in the control group.

\begin{tabular}{|c|c|c|c|}
\hline & $\begin{array}{c}\text { Exercise } \\
\text { p (paired t test) }\end{array}$ & $\begin{array}{c}\text { Control } \\
\text { p (paired t test) }\end{array}$ & $\begin{array}{l}\text { Exercise vs. Control } \\
\text { p (unpaired t test) }\end{array}$ \\
\hline$\Delta$ Creatinine $(\mu \mathrm{mol} / \mathrm{l})$ & $\begin{array}{c}-33.4 \pm 54.8 \\
(n=26) \\
p=0.005\end{array}$ & $\begin{array}{c}-28.5 \pm 41.7 \\
(n=36) \\
p=0.0002\end{array}$ & 0.715 \\
\hline $\begin{array}{l}\Delta \text { Circulating stem cells } \\
(\text { cells } / \mathrm{ml})\end{array}$ & $\begin{array}{c}-691 \pm 1472 \\
(n=21) \\
p=0.044\end{array}$ & $\begin{array}{c}-487 \pm 1811 \\
(n=25) \\
p=0.191\end{array}$ & 0.681 \\
\hline $\begin{array}{l}\triangle \text { Circulating endothelial } \\
\text { progenitor cells }(\text { cells } / \mathrm{ml})\end{array}$ & $\begin{array}{c}-48 \pm 150 \\
(\mathrm{n}=21) \\
\mathrm{p}=0.163\end{array}$ & $\begin{array}{c}+131 \pm 250 \\
(n=25) \\
p=0.015\end{array}$ & 0.006 \\
\hline $\begin{array}{l}\triangle \text { Circulating microparticles } \\
\left(n M P S^{*}\right)\end{array}$ & $\begin{array}{c}+0.825 \pm 3.4 \\
(n=16) \\
p=0.346\end{array}$ & $\begin{array}{c}+1.880 \pm 2.8 \\
(n=19) \\
p=0.0099\end{array}$ & 0.321 \\
\hline $\begin{array}{l}\triangle \text { Asymmetric dimethyl arginine } \\
(\mu \mathrm{mol} / \mathrm{l})\end{array}$ & $\begin{array}{c}-0.139 \pm 0.181 \\
(n=26) \\
p=0.0006\end{array}$ & $\begin{array}{c}-0.106 \pm 0.205 \\
(n=36) \\
p=0.004\end{array}$ & 0.421 \\
\hline
\end{tabular}

Data are mean $\pm \mathrm{SD}, *$ nM PS: nanomoles per liter relative to phosphatidylserine.

In conclusion, circulating endothelial progenitor cells decreased in renal transplant recipients after 6 months of exercise program in comparison to the control group not exposed to this intervention. In other parameters reflecting vascular health, no significant differences were detected between intervention and control group. Similar findings were found for men and women. According to the previously published data, while resumption of renal function results in a mild rise in the number of circulating endothelial progenitor cell, their levels are still lower than in healthy individuals (Werner et al. 2005, Herbrig et al. 2006, Steiner et al. 2006). We suppose that the effect of exercise on endothelial progenitor cells could be in patients after renal transplantation modulated by long-term immunosuppressive drugs (cyclosporin or tacrolimus) which can have from this point of view rather unpredictable effect on the bone marrow and exact mechanism of these processes is unknown (Riegersperger et al. 2013). The additional explanation could be a chronic activation of reparative mechanisms of vascular system in subjects exposed to multiple cardiovascular risk factors and subsequent relative stabilization of these processes by lifestyle intervention. Recently, Rocha et al. (2015) described that patients with metabolic syndrome were not able to prevent by an exercise program a decline in endothelial progenitor cells induced by mental stress. This observation could be partly pertinent also to renal transplant recipients, substantial proportion of which also manifests the presence of several metabolic risk factors. From this point of view, it is also noteworthy, that circulating microparticles as a marker of vascular damage in our study tended to increase more in the control group than in the intervention group. Despite the fact that their changes were not significantly different between intervention and control group, this observation could also support our hypothesis of amelioration of inappropriate activation of vascular system by exercise in renal transplant recipients. The effect of exercise on parameters under study could be also transient and could be relatively rapidly abolished after the termination of the exercise program. Therefore, it might be difficult to 
detect its effect if not evaluated immediately after the end of the intervention, which was the case of this study.

The main limitations of this study are that it is not a randomized study and that not all patients were examined immediately after the intervention. Another limitation is the absence of analysis of long-term effects of exercise program and the absence of analysis of the changes in other factors like body weight and lipid/glucose parameters. The potential role of a longterm use of immunosuppressive drugs should also be analyzed more precisely, but the statistical power of such analysis will not be sufficient due to a relatively low number of participants. On the other hand, we present the data from a unique population of renal transplant recipients exposed to lifestyle intervention using sophisticated laboratory measurements of vascular and endothelial parameters, which could stimulate further research in this field.

\section{Conflict of Interest}

There is no conflict of interest.

\section{Acknowledgements}

The study was supported by Grant NT/13139-2/2012 awarded by the Internal Grant Agency of the Czech Republic.

\section{References}

BOGER RH: Association of asymmetric dimethylarginine and endothelial dysfunction. Clin Chem Lab Med 41: 14671472, 2003.

HERBRIG K, PISTROSCH F, FOERSTER S, GROSS P: Endothelial progenitor cells in chronic renal insufficiency. Kidney Blood Press Res 29: 24-31, 2006.

IVAK P, PITHA J, WOHLFAHRT P, KRALOVA LESNA I, STAVEK P, DORAZILOVA Z, STEPANKOVA J, MALY J, POKORNY M, NETUKA I: Endothelial dysfunction expressed as endothelial microparticles in patients with end-stage heart failure. Physiol Res 63 (Suppl 3): S369-S373, 2014.

MITTERMAYER F, PLEINER J, KRZYZANOWSKA K, WIESINGER GF, FRANCESCONI M, WOLZT M: Regular physical exercise normalizes elevated asymmetrical dimethylarginine concentrations in patients with Type 1 diabetes mellitus. Wien Klin Wochenschr 23-24: 816-820, 2005.

PITHA J, TEPLAN V, KALOUSOVA M, RACEK J, STOLLOVA M, MAREČKOVÁ O, LANSKA V: Gender-related determinants of advanced subclinical atherosclerosis in patients undergoing kidney transplantation. Kidney Blood Press Res 33: 227-234, 2010.

RIEGERSPERGER M, PLISCHKE M, STEINER S, SEIDINGER D, SENGOELGE G, WINKELMAYER WC, SUNDER-PLASSMANN G: Effect of conversion from ciclosporin to tacrolimus on endothelial progenitor cells in stable long-term kidney transplant recipients. Transplantation 95: 1338-1345, 2013.

ROCHA NG, SALES AR, MIRANDA RL, SILVA MS, SILVA JF, SILVA BM, SANTOS AA, NÓBREGA AC: Aerobic exercise modulation of mental stress-induced responses in cultured endothelial progenitor cells from healthy and metabolic syndrome subjects. Life Sci 123: 93-99, 2015.

SCHLAGER O, GIURGEA A, SCHUFRIED O: Exercise training increases endothelial progenitor cells and decreases asymmetric dimethylarginine in peripheral arterial disease: a randomized controlled trial. Atherosclerosis 217: 240-244, 2011.

SLAVÍK L: Microparticles (in Czech). In Vitro Diagnostics 16: 19-22, 2010.

STEINER S, WINKELMAYER WC, KLEINERT J: Endothelial progenitor cells in kidney transplant recipients. Transplantation 81: 599-603, 2006.

ULBICH C, DIMMELER S: Endothelial progenitor cells. Characterisation and role in vascular biology. Circ Res 95 : 343-347, 2004.

WERNER N, KOSIOL S, SCHIEGL T, AHLERS P, WALENTA K, LINK A, BOEHM M, NICKENIG G: Circulating endothelial progenitor cells and cardiovascular outcomes. N Engl J Med 353: 999-1007, 2005. 